\title{
Pengaruh Senam Yoga Terhadap Perubahan Gula Darah Pada Pasien Diabetes Mellitus Tipe II di Wilayah Kerja Puskesmas Cakranegara Mataram Tahun 2018
}

\author{
Siti Hardianti Rukmana ${ }^{1)}$, Irwan Hadi $^{2}$, Marthilda Suprayitna ${ }^{3)}$ \\ E-mail: marthildasuprayitna@gmail.com \\ 1) Mahasiswa STIKES YARSI Mataram PRODI Keperawatan Jenjang S.1 \\ 2) Dosen STIKES YARSI Mataram PRODI Keperawatan Jenjang S1 \\ 3) Dosen STIKES YARSI Mataram PRODI Keperawatan Jenjang D.III
}

\begin{abstract}
ABSTRAK
Diabetes Mellitus(DM) merupakan penyakit yang diletupkan oleh interaksi berbagai faktor: genetik, imunologik, lingkungan, dan gaya hidup. Kurangnya aktifitas fisik, stress dan usia yang semakin tua mengakibatkan insulin yang dihasilkan akan berkurang karena fungsi pankreas menurun, maka olahraga dianjurkan untuk mengontrol kadar gula darah, salah satunya yaitu senam yoga. Penelitian ini bertujuan untuk mengetahui pengaruh senam yoga terhadap terhadap perubahan kadar gula darah pada pasien Diabetes Mellitus tipe II di Wilayah Kerja Puskesmas Cakranegara. Penelitian ini menggunakan desain penelitian Quasy Experiment dengan pendekatan Pre and Post Test Without Control. Sampel pada penelitian ini 10 orang penderita Diabetes Mellitus tipe II di Wilayah Kerja Puskesmas Cakranegara. Hasil analisis uji T ( Paired Sample ) di peroleh $\mathrm{p}=0,006<0,05$. Dapat disimpulkan bahwa ada pengaruh Senam Yoga terhadap Perubahan kadar gula darah pada pasien Diabetes Mellitus tipe II di Wilayah Kerja Puskesmas Cakra Negara diharapkan bagi pelayanan kesehatan agar dapat menjadi motivator bagi penderita Diabetes Mellitus melakukan senam yoga untuk mengrol kadar gula darah dan mencegah komplikasi.
\end{abstract}

Kata Kunci : DM, Senam Yoga, Gula Darah

\begin{abstract}
Diabetes Mellitu (DM) is a disease that is exposed by the interaction of various factors : genetic, immunologic, environmental, and lifestyle. Lack of physical activity, stress and anincreasing old age resulted in reduced insulin will decrease because the function of pancreas decreased, than exercise is recommended to control blood sugar levels, one of which is yoga exercise. This study aims to determine the effect of yoga on changes blood sugar levels in patients with diabetes mellitus type II in Working Area Of Cakra Negara Public Health Center. This research is Quasy Xperiment with pre and post without control approach. The samples in this research were 10 people with DM in Cakra Negara Public Health Center. Result of T test analysis (Paired Sample) obtained $p=0,006<0,05$. It can concluded that there is an effect of gymnastic yoga toward blood sugar levels changes in patient with DM type II in Cakra Negara public health center, frpm this research hoped for health services in order to be a motivator for people with DM to do gymnastic yoga to control blood sugar levels and prevent complication.
\end{abstract}

Keywords: Diabetes Mellitus (DM), Gymnastic Yoga, Blood Sugar

\section{A. LATAR BELAKANG}

Penyakit Diabetes Mellitus (DM) merupakan suatu penyakit Kronis yang komplek melibatkan kelainan metabolisme karbohidrat, protein dan lemak serta berkembangnya komplikasi nakrovaskuler dan neurologis. Diabetes Mellitus merupakan sekelompok kelainan yang ditandai oleh peningkatan kadar glukosa darah (hiperglikemia) dan mungkin terdapat penurunan dalam melakukan kemampuan untuk berespon 
terhadap insulin maupun adanya penurunan pembentukan insulin oleh pankreas[1].

World health organization (WHO) mengemukakan bahwa Indonesia akan menempati peringkat nomor lima sedunia dengan jumlah pengidap diabetes sebanyak 12,4 juta orang pada tahun 2025. WHO membuat perkiraan bahwa pada tahun 2025. WHO membuat perkiraan bahwa pada tahun 2000 jumlah pengidap diabetes di atas umur 20 tahun[2]. Menurut penelitian epedemiologi yang saat ini di laksanakan di Indonesia, kekerapan diabetes di Indonesia berkisar antara 1,4 dengan $1,6 \%$ kecuali di dua tempat yaitu di pekajangan $2,3 \%$ dan menado $6 \%[2]$.

Kasus diabetes melitus di Nusa Tenggara Barat (NTB) untuk penyakit Diabetes Mellitusprevalensi sebesar 1,8\% 5,9\% dengan angka tertinggi di kabupaten Bima dan terdapat di semua kabupaten/kota[3]. Kasus diabetes melitus di NTB memiliki prevalensi di atas prevalensi nasional diabetes yaitu $4,1 \%$. Prevalensi nasional penyakit Diabetes Mellitus adalah $1,1 \%$ (berdasarkan diagnosis tenaga kesehatan dan gejala)[3].

Data yang diperoleh dari Dinas Kesehatan Provinsi NTB dalam 3 tahun Terakhir (20132015) jumlah kasus penderita Diabetes Mellitus pada tahun 2013 sejumlah 9.171 jiwa terdiri dari 3840 orang penderita Diabetes Mellitus laki laki dan 5331 orang penderita diabetes melitus perempuan. Tahun 2014 jumlah penderita Diabetes Mellitus 6504 jiwa terdiri dari 2691 penderita Diabetes Mellitus laki - laki dan 2691 penderita Diabetes Mellitus perempuan. Pada tahun 2015 jumlah penderita Diabetes Mellitus53.687 jiwa terdiri dari 21.400 penderita Diabetes Mellitus laki - laki dan 32287 penderita Diabetes Mellitus perempuan.

Pada umumnya Diabetes Mellitus tipe II terjadi secara bertahap oleh karena itu mencermati dari gejala -gejala dari diabetes ini menjadi sangat penting[4]. Komplikasi kronik jika kadar gula darah yang normal tidak dipertahankan secara teratur. Orang yang mengidap Diabetes Mellitus kemungkinan besar mengalami penyakit pada jantung, pembulu darah, ginjal, mata dan saraf. Komplikasi dapat dicegah dengan mengontrol kadar gula darah, mempertahankan tekanan darah yang normal, dan melakukan olahraga yang rutin[5]. Melihat komplikasi dan ancaman jumlah penderitanya, diabetes melitus harus diatasi sedini mungkin. Kuncinya rajinlah berolahraga dan lakukan diet, obat-obatan hanya sebagai penunjang. Orang yang tidak berolahraga memerlukan insulin dua kali lebih banyak untuk menurunkan kadar glukosa dalam darahnya dibandingkan orang yang berolahraga[6].

Upaya dari olahraga bagi pasien Diabetes Mellitus perlu dilakukan usaha untuk mengembalikan kadar glukosa darah pada pasien Diabetes Mellitus tipe II dapat dilakukan dengan pengelolaan non farmakologis salah satunyakegiatan jasmani yaitu dengan olahraga yoga. Berlatih yoga secara teratur sangat berguna bagi penderita diabetes. Latihan yoga menyebabkan otot-otot untuk menyerap kelebihan glukosa dalam darah. Yoga membantu pankreas dan hati untuk berfungsi secara efektif,dengan jalan mengatur kadar gula darah. Gerakan -gerakan yoga yang bertujuan untuk merangsang fungsi kerja pankreas,meremajakan sel -sel organ dan meningkatkan kemampuan panreas untuk memproduksi insulin[7].

Pada pasien Diabetes Mellitus tipe II olahraga senam yoga sebagai pengatur kadar glukosa darah,produksi insulin umumnya tidak tergantung terutama pada awal penderita penyakit Diabetes Mellitus tipe II. Kurangnya reseptor pada insulin menjadi masalah utama pada Diabetes Mellitus tipe II karena adanya gangguan tersebut insulin tidak dapat membantu transfer glukosa ke dalam sel. Pada saat olahraga resistensi insulin berkurang, sebaliknya sensitifitas insulin meningkat hal tersebut menyebabkan kebutuhan insulin pada diabetes melitus tipe II akan berkurang. Respon ini hanya terjadi setiap kali berolahraga dan tidak merupakan efek yang menetap dan berlangsung lama. Maka dari itu bagi penderita Diabetes Mellitus tipe II olahraga harus dilakukan secara 
teratur[8]

Berdasarkan penelitian yang dilakukan oleh Nurul Fatiah[9] dengan judul "Pengaruh Senam Aerobik dan Yoga Terhadap Perubahan Kadar Gula Darah Pada Pasien Diabetes Mellitus tipe II di poli klinik penyakit dalam RSUP M. Djamil Padang "hasil penelitian ini menunjukkan penurunan rata-rata kadar gula darah dengan senam aerobik adalah $32 \mathrm{mg} / \mathrm{dl}$ dan penurunan rata-rata dengan yoga adalah $47,7 \mathrm{mg} / \mathrm{dl}$.Hasil uji statistik kelompok eksperimen dan pembanding didapatkan nilai $\mathrm{p}=0,038(\mathrm{p}<0,05)$ yang berarti dapat menurunkan kadar gula darah pada pasien Diabetes Mellitus tipe II. Disarankan untuk melakukan yoga sebagai salah satu olahraga yang dapat menurunkan kadar gula pada pasien Diabetes Mellitus tipe II.

Diabetes Mellitus tipe II merupakan penyakit diabetes yang disebabkan karena sel-sel tubuh tidak menggunakan insulin sebagai sumber energi atau sel-sel tubuh tidak merespon yang dilepaskan pankreas. Pasien Diabetes Mellitus kemungkinan besar mengalami komplikasi, antara lain penyakit jantung, pembuluh darah, ginjal, mata dan saraf. Komplikasi tersebut dapat dicegah dengan mengontrol kadar gula darah, pertahankan tekanan darah yang normal dan lakukan olahraga.

Yoga adalah salah satu olahraga yang dapat alternatif untuk penyembuhan berbagai macam penyakit misalnya Diabetes Mellitus tipe 2. Yoga memiliki efek detoksifikasi yang dapat mengeluarkan racun dari tubuh, sehingga memberikan bantuan dari berbagai gangguan atau penyakit di dalam tubuh. Yoga merupakan olahraga yang baik untuk melatih pernapasan sehingga paru - paru dan jantung menjadi lebih sehat. Untuk itu senam yoga akan lebih membantu penderita Diabetes Mellitus tipe 2, dan diharapkan penderita dapat memperoleh kesembuhannya serta termotivasi untuk gemar berolahraga[10].

Durasi latihan yoga yang dilakukan secara teratur menunjukan hasil efektif dibandingkan latihan fisik lainnya. Perubahan positif tersebut terjadi melalui 2 jalur yaitu Hypothalamic
Pituitary Adrenal (HPA) axis atau mengurangi aktivitas system symphato-adrenal. Dimana aktifasi HPA axis dan system symphato-adrenal dapat meningkatkan resistensi insulin, inhibisi pelepasan insulin dan meningkatkan produksi gluosa hepatic. Gerakan yoga seperti peregangan dapat meningkatkan sensivitas glukosa dan meningkatkan clearance glukosa[11].

Gerakan - gerakan yoga terdiri dari beberapa tahapan yaitu mulai dari pemanasan,gerakana inti,olah nafas dan berakhir dengan meditasi. Pemanasan dilakukan kurang lebih selama 15 menit, gerakan inti selama 30 menit dan diakhiri dengan relaksasi selama 15 menit[12]. Latihan yoga yang dilakukan sembilan kali dalam seminggu akan efektif dalam menurunkan kadar gula darah sewaktu pada penderita Diabetes Mellitus tipe 2.

Upaya yang perlu dilakukan untuk usaha mengendalikan kadar glukosa darah pada pasien Diabetes Mellitus tipe II dapat dilakukan dengan pengelolaan non farmakologis, berupa kegiatan jasmani yaitu dengan olahraga yoga. Gerakangerakan yoga yang dilakukan adalah gerakan gerakan yoga yang bertujuan untuk merangsang fungsi kerja pankreas, fungsi gerakangerakantersebut akan meningkatkan aliran darah ke pankreas, meremajakan sel-sel organ dan meningkatkan kemampuan pankreas untuk memproduksi insulin.

Penelitian ini bertujuan untuk mengetahui apakah ada Pengaruh Senam Yoga Terhadap Perubahan Kadar Gula Darah Pada Pasien Diabetes Mellitus tipe II di wilayah Puskemas Cakranegara".

\section{B. METODE PENELITIAN}

Metode penelitian ini adalah kuantitiatif dengan desain Eksperimen semu (quasy experiment design). Populasi dalam penelitian ini adalah pasien Diabetes Mellitus tipe II di wilayah kerja puskesmas Cakranegara kota Mataram populasi di ambil 2 Kelurahan. Teknik pengambilan sampel pada menggunakan teknik Probability sampling dengan jumlah responden 10 orang. Responden yang memenuhi kriteria 
inklusi dan eksklusi diberikan Senam Yoga. Data dianalisis secara univariat dan bivariat. Analisis Univariat untuk mendeskripsikan karakteristik setiap variabel penelitian yaitu umur, jenis kelamin, status pekerjaan dan nilai kadar gula darah, analisis bivariat digunakan untuk membedakan sebelum dan sesudah intervensi menggunakan uji paired $\mathrm{T}$ test dependen.

\section{HASIL DAN PEMBAHASAN}

Pada Tabel 1, dapat dilihat karakteristik responden di wilayah kerja puskesmas Cakra Negara Kota Mataram tahun 2018.

Tabel 1. Karakteristik responden di wilayah kerja puskesmas Cakra Negara Kota Mataram tahun 2018

\begin{tabular}{|c|c|c|}
\hline \multirow{2}{*}{ Variabel } & \multicolumn{2}{|c|}{ Intervensi } \\
\hline & $\mathrm{F}$ & $\%$ \\
\hline \multirow{4}{*}{$\begin{array}{l}\text { Umur } \\
-42-48 \text { tahun } \\
-49-54 \text { tahun } \\
-55-59 \text { tahun }\end{array}$} & & \\
\hline & 3 & 30 \\
\hline & 4 & 40 \\
\hline & 3 & 30 \\
\hline Total & 10 & 100 \\
\hline \multicolumn{3}{|l|}{ Jenis kelamin } \\
\hline - Laki-laki & 3 & 30 \\
\hline - Perempuan & 7 & 70 \\
\hline Total & 10 & 100 \\
\hline \multicolumn{3}{|l|}{ Pekerjaan } \\
\hline - Pedagang & 2 & 20 \\
\hline - IRT & 4 & 40 \\
\hline - PNS & 2 & 20 \\
\hline - Pegawai Swasta & 2 & 20 \\
\hline Total & 10 & 100 \\
\hline
\end{tabular}

Berdasarkan hasil penelitian didapatkan data pada umur responden yang memiliki nilai tinggi yaitu responden yang berumur antara $(49-54)$ sebanyak 4 orang (40\%). Dengan jenis kelamin perempuan yang mendominasi sebanyak 7 orang (70\%), dengan pekerjaan IRT sebanyak 4 orang $(40 \%)$.

Tabel 2. Hasil Uji T ( paired sample ) Nilai Kadar Gula Darah Responden Sebelum dan Sesudah Dilakukan Senam Yoga

\begin{tabular}{|l|c|c|c|c|c|}
\hline Variabel & Mean & SD & SE & $\begin{array}{c}\text { P } \\
\text { value }\end{array}$ & $\mathrm{N}$ \\
\hline $\begin{array}{l}\text { Gula darah pre } \\
\text { intervensi }\end{array}$ & 222,5 & 127,9 & 40,4 & & \\
\cline { 1 - 3 } $\begin{array}{l}\text { Gula darah } \\
\text { post intervensi }\end{array}$ & 207,6 & 120,6 & 38,1 & 0,006 & 10 \\
\hline
\end{tabular}

Analisis univariat dalam penelitian ini data dijelaskan mengenai pengukuran gula darah sebelum dan sesudah intervensi.

Nilai gula darah responden sebelum melakukan senam yoga dan sesudah melakukan senam yoga menunjukkan bahwa hasil uji $\mathrm{T}$ (paired sample) diperoleh hasil rata-rata pengukuran kadar gula darah sebelum intervensi $222.5 \mathrm{mg} / \mathrm{dl}$ dengan standar deviasi $127.9 \mathrm{mg} / \mathrm{dl}$ pada nilai pengukuran kadar nilai kadar gula darah responden setelah intervensi didapatkan rara-rata $207.6 \mathrm{mg} / \mathrm{dl}$ dengan standar deviasi $120.6 \mathrm{mg} / \mathrm{dl}$. Hasil uji statistik didapatkan nilai $\mathrm{p}$ value $0.006<0.05$, maka Ho ditolak. Berarti ada pengaruh senam yoga terhadap perubahan kadargula darah pasien Diabetes Mellitus tipe II di wilayah kerja Puskesmas Cakra Negara.

Hasil penelitian terhadap 10 responden ini, nilai rata-rata kadar gula darah responden sebelum melakukan senam yoga menunjukkan bahwa rata-rata nilai kadar gula darah responden dengan Diabetes Mellitus sebelum melakukan senam yoga yaitu $222.5 \mathrm{mg} / \mathrm{dl}$ dengan standar deviasi $127.9 \mathrm{mg} / \mathrm{dl}$. Nilai kadar gula darah responden terendah $141 \mathrm{mg} / \mathrm{dl}$ dan tertinggi 515 $\mathrm{mg} / \mathrm{dl}$.

Menurut PERKENI[13] faktor resiko terjadinya faktor risiko yang tidak bisa dimodifikasi yaitu ras dan etnik, riwayat keluarga dengan diabetes (anak penyandang diabetes), umur risiko untuk menderita intoleransi glukosa meningkat seiring dengan meningkatnya usia. Usia > 45 tahun, riwayat melahirkan Bayi dengan berat badan lahir bayi > 4000 gram atau riwayat pernah menderita diabetes melitus gestasional, riwayat lahir dengan berat badan rendah, kurang dari $2,5 \mathrm{~kg}$.

Pada penelitian yang sudah dilakukan karakteristik responden berdasarkan tingkat umur yang memiliki nilai tinggi yaitu responden yang berumur antara ( 49 tahun sampai 54 tahun) yaitu sebanyak 4 orang responden (40\%) dan tingkat umur yang memiliki nilai terendah yaitu responden yang berumur antara (42 tahun sampai 48 tahun) yaitu sebanyak 3 orang (30\%) dan (55 tahun sampai 59 tahun) sebanyak 3 orang 
$(30,0 \%)$.

Engkartini menyebutkan bahwa perempuan lebih banyak menderita diabetes melitus dibandingkan laki-laki. Hal ini dipicu oleh adanya persentase timbunan lemak badan pada wanita yanglebih besar dibandingkan dengan laki-laki yang menjadi salah satu faktor yang dapat menurunkan sensitifitas terhadap kerja insulin pada otot dan hati.

Nilai pengukuran gula darah responden setelah melakukan Senam Yoga.

Hasil penelitian terhadap 10 responden ini, nilai rata-rata kadar gula responden sesudah melakukan senam yoga menunjukkan bahwa rata-rata nilai kadar gula darah responden dengan Diabetes Mellitussetelah melakukan senam yoga yaitu $208.47 \mathrm{mg} / \mathrm{dl}$ dengan standar deviasi $117.586 \mathrm{mg} / \mathrm{dl}$. Nilai kadar gula darah responden terendah $134 \mathrm{mg} / \mathrm{dl}$ dan tertinggi 500 .

Aktivitas olahraga sangat berpengaruh terhadap pengendalian kadar gula darah. Melakukan olahraga yang baik dan teratur membuat peningkatan aliran ke otot dengan cara pembukaan kapiler (pembuluh darah kecil diotot) dan hal ini akan menurunka tekanan pada otot yang pada gilirannya akan meningkatkan penyediaan dalam jaringan otot itu sendiri. Dengan demikian akan mengurangi gangguan metabolisme karbohidrat pada penderita Diabetes Mellitus sehingga menurunkan kadar glukosanya. Tujuan olahraga untuk meningkatkan kepekaan insulin, mencegah kegemukan, memperbaiki aliran darah, merangsang pembentukan glukogen baru [8].

Menurut Horden et al., menyatakan olahraga yang dianjurkan bagipenderita Diabetes Mellitusadalah aerobic low impact danrithmis, misalnya berenang, jogging, naik sepeda,dan senam, karena menggunakan semua otot- otot besar, pernapasan dan jantung. Gerakan senam yoga bermanfaat untuk menurunkan kimiawi darah. Gerakan yoga yang dapat menurunkan gula darah, kolesterol jahat, menurunkan berat badan, dan memperbaiki sensitivitas pada insulin. Gerakan senam aerobic menggunakan otot besar dilakukan secara terus menerusdan berirama dapat meningkatkansensitivitas reseptor insulin. Peningkatan reseptor tersebut mampu meningkatkan transfer glukosa ke sel, sehingga terjadi penurunan kadar glukosa darah pada penderita Diabetes Mellitus tipe II. Pernafasan Yoga yang membuat gerakan turun naik perut akan menekan kerja pankreas. Hal ini membuat hormone insulin menjadi aktif dan kebutuhan insulin menjadi berkurang, sehingga tidak terjadi peningkatan kadar gula darah [6].

Dalam penelitian ini senam yoga dilakukan dengan cara mengumpulkan semua responden diabetes melitus tipe II di dalam ruangan, yang waktunya dilakukan pada sore hari. Kemudian responden diabetes melitus mengikuti langkah langkah senam yoga yang dilakukan oleh istruktur yoga dan dilakukan pengukuran gula darah sebelum dan sesudah melakukan senam yoga. Diabetes melitus merupakan penyakit yang tidak bisa disembuhkan melainkan hanya dapat dikontrol kadar gula darahnya. Tetapi olahraga juga berperan utama dalam pengaturan kadar gula darah[8]. Senam yoga dibutuhkan untuk membakar kelebihan glukosa di dalam tubuh, olahraga yoga memacu badan untuk lebih efektif menggunakan karbohidrat[6]. Olahraga untuk menurukan kadar gula selain senam yoga, bisa juga melakukan jalan kaki selama 30 menit, seperti penelitian yang dilakukan oleh Daniar reza hermawan dan Haqqul Falahi[14], melakukan penelitian tentang "Pengaruh jalan kaki selama 30 menit terhadap perubahan gula darah pada pasien Diabetes Mellitus tipe II di wilayah puskesmas kedungwuni II kabupaten pekalongan". Hasil uji statistik menunjukkan $\mathrm{p}$ value gula darah sebelum dan sesudah melakukan jalan kaki selama 30 menit $(0,001)$ lebih kecil dari nilai alvha $(0,05)$ sehingga Ho di tolak, jadi ada pengaruh jalan kaki selama 30 menit terhadap perubahan gula darah pada pasien Diabetes Mellitus tipe II.

Pengaruh senam yoga terhadap perubahan kadar gula darah pada pasien diabetes melitus tipe II

Hasil penelitian ini menunjukkan bahwa hasil uji $\mathrm{T}$ (paired sample) diperoleh hasil rata- 
rata pengukuran kadar gula darah sebelum intervensi $222.5 \mathrm{mg} / \mathrm{dl}$ dengan standar deviasi $127.9 \mathrm{mg} / \mathrm{dl}$ pada nilai pengukuran kadar nilai kadar gula darah responden setelah intervensi didapatkan rara-rata $207.6 \mathrm{mg} / \mathrm{dl}$ dengan standar deviasi $120.6 \mathrm{mg} / \mathrm{dl}$. Hasil uji statistik didapatkan nilai $\mathrm{p}$ value $0.006<0.05$, maka Ho ditolak. Berarti ada pengaruh senam yoga terhadap perubahan kadar gula darah pasien Diabetes Mellitus tipe II di wilayah kerja Puskesmas Cakra Negara.

Berdasarkan penelitian yang dilakukan oleh Intan[10] tentang “ Pengaruh Latihan Senam Yoga Terhadap Kadar Glukosa Darah dan Kolesterol Pada Penderita Diabetes Mellitus tipe 2 " hasilnya menunjukkan bahwa Senam Yoga dapat menurunkan kimiawi darah secara signifikan, terbukti dari nilai $\mathrm{p}=0.000<0.05$, ada perbedaan pengaruhpenurunan kadar glukosa darah yang signifikan antara penderita Diabetes Mellitus tipe 2 dengan kadar glukosa Darah $<250 \mathrm{mg} / \mathrm{dl}$ dan $>250 \mathrm{mg} / \mathrm{dl}$, terbukti dari nilai $\mathrm{p}=0.000<0.05$, Latihan senam yoga memberikan pengaruh yang baik terhadap penurunan kimiawi darah.

Hasil penelitian dengan satu kali pengukuran kadar Gula setelah senam yoga dilakukan menunjukkan adanya pengaruh antara senam yoga dengan kadar gula darah. Namun pengaruh yang diperoleh dalam penelitian ini, bahwa senam yoga tidak mempengaruhi secara signifikan dalam perubahan kadar gula darah. Karena rata-rata yang dihasilkan sebelum dan sesudah melakukan senam yoga adalah 14,9 $\mathrm{mg} / \mathrm{dl}$ lebih kecil dari penelitian yang dilakukan oleh Nurul Fatia yang memperoleh rata-rata perubahan sebesar 47,7 mg/dl. Hal ini disebabkan karena perlakuan yang diberikan kepada responden hanya satu kali. Berdasarkan teori yang ada bahwa senam yoga idealnya dilakukan dua atau tiga kali dalam seminggu dengan frekuensi latihan 1,5 jam[7].

\section{KESIMPULAN}

1. Rata-rata kadar gula darah sebelum diberikan senam yoga sebesar $222.5 \mathrm{mg} / \mathrm{dl}$.
2. Rata-rata kadar gula darah sesudah diberikan senam yoga sebesar $207.6 \mathrm{mg} / \mathrm{dl}$.

3. Berdasarkan uji $\mathrm{T}$ (paired sample) diperoleh $\mathrm{p}$ value kadar gula darah sebelum dan sesudah senam yoga sebesar $0.006<0.05$, maka Ho ditolak, berarti ada pengaruh senam yoga terhadap perubahan kadar gula darah pada pasien diabetes melitus tipe II di wilayah kerja puskesmas Cakra Negara kota Mataram

\section{DAFTAR PUSTAKA}

[1] Riyadi, Sujono. 2013. Asuhan Keperawatan Pada Pasien Dengan GangguanEksokrin dan Endokrin Pada Pankreas. Graha Ilmu : Yogyakarta.

[2] Sudoyo,Aru dkk. 2014. Ilmu Penyakit Dalam Edisi VI JIlid II.Interna Publishing ; Jakarta.

[3] Kemenkes RI. 2013. Riset Kesehatan Dasar. RISKESDAS.Jakarta. Balitbang Kemenkes RI

[4] Sutanto. 2013. Diabetes Deteksi, pencegah, pengobatan. Buku Pintar: Yogyakarta.

[5] Ramaidah, Savitri. 2006. Diabetes : Cara Mengetahui Gejala Diabetes danMendeteksinya Sejak Dini. PT Bhuana Ilmu Populer: Jakarta.

[6] Surya, Dharma. 2006.Taklukan Diabetes Dengan Yoga. Puspa Swara: Jakarta.

[7] Widya, Setta. 2015. Panduan Dasar Yoga. PT Kawan Pustaka: Jakarta

[8] Soegondo, dkk. 2011. Penatalaksanaan Diabetes Melitus Terpadu.Badan penerbit FKUI: Jakarta.

[9] Nurul Fatia. 2012.Perbedaan Pengaruh Senam Aerobik dan Yoga TerhadapPenurunan Kadar Gula Darah Pada Pasien Diabetes Melitus Tipe II Di Poliklinik Khusus Penyakit Dalam RSUP M. Djamil, Padang.

[10] Intan,Imawati. 2017. Pengaruh Latihan Senam Yoga Terhadap Kadar Glukosa Darah dan Kolesterol Pada Penderita Diabetes Mellitus tipe 2. Pendidikan Olahraga FKIP, Universitas Kader Bangsa.Jurnal Jendela Olahraga.Volume 2 Nomor Availablehttp://www.google.co.id/url?q=ht tp://journal.upgris.ac.id/index.php/jendelao 
lahraga/article/download/1706/1416\&sa $=\mathrm{U}$ \&ved=0ahUKEwjxh8Xqga_ZAhVClZQK HdXBzYQFgggMAI\&usg=AOvVaw3cM Vi91pGTHk25SODSO6B5. Pada tanggal 15 Januari 2018

[11] Venugopal ,V; Rathi, Amit; Raghuram, Nagarthna. 2017. Effect of Short-term Yoga -based Lifestyle Intervention on Plasma Glucose Lvels in Individuals with Diabetes and Pre-Diabetes in the Community. Diabetes\& Metabolic Syndrome: Clinical Research \& Reviews.

[12] Wirawanda, Y. 2014. Kedasyatan terapi Yoga. Jakarta: Pajja

[13] PERKENI. 2015.Pengelolaan dan Pencegahan Diabetes Melitus Tipe 2 diIndonesia, PERKENI:Jakarta.

[14] Daniar Reza \& Haqqul F. 2013. Pengaruh Jalan Kaki Selama 30 Menit TerhadapPerubahan Gula Darah Pada Pasien Diabetes Melitus Tipe II Di Wilayah Puskesmas Kedungwuni II Kabupaten Pekalongan, Stikes MuhammadiyahPekajangan Pekalongan. 